\title{
Mandibular Foramen Location and Lingula Height in Dentate Dry Mandibles, and its Relationship With Cephalic Index
}

\author{
Localización del Foramen Mandibular y Altura de la Língula Mandibular \\ en Mandíbulas Dentadas Secas, y su Relación con el Índice Cefálico
}

Atson Carlos de Souza Fernandes*; Raquel Pimentel Loureiro**; Leonardo Oliveira** \& Márcio de Moraes***

FERNANDES, A. C. S.; LOUREIRO, R. P.; OLIVEIRA, L. \& DE MORAES, M. Mandibular foramen location and lingula height in dentate dry mandibles, and its relationship with cephalic index. Int. J. Morphol., 33(3):1038-1044, 2015.

SUMMARY: The mandibular foramen and its lingula is a major landmark when administering anesthetic or performing surgical procedures. The objective of this study was to determine whether the topological features of the mandibular foramen (MF) and lingula varied in mandibles from skulls of different cephalic indexes. The location of the mandibular foramen referred to the longitudinal borders of the mandibular ramus (MR), height of the foramen (Hf) referred to the occlusal line of the second molar, and the height of the lingula $(\mathrm{Hl})$ were determined in a total of one hundred and five dry mandibles from skulls identified as dolicho- meso- and brachycephalic. On average MF in brachycephalic mandibles was closest to the anterior border of MR. Hf in brachy-, meso- and dolichocephalic mandibles were $-0.22 \mathrm{~mm},-4.04 \mathrm{~mm}$ and $-4,01 \mathrm{~mm}$, respectively. The lingula in brachycephalic specimens was considerably shorter $(0.78 \mathrm{~mm})$ than in dolichocephalic ones $(1.84 \mathrm{~mm})$. Inferior alveolar nerve block should be carried out using shorter needles, inserting it $4 \mathrm{~mm}$ above the occlusion level of the molar teeth. The ramus of brachicephalic mandibles were significantly less wide those of dolicho- and mesocephalic ones. If the height of the lingula is to be used as a reference to judge the level of the medial horizontal cut to carry out sagittal split ramus osteotomy, special attention should be given to the patient's cephalic index.

KEY WORDS: Lingula; Mandibular foramen; Cephalic index.

\section{INTRODUCTION}

Mandibular foramen and lingula of the mandible are important anatomic landmarks described in textbooks and scientific papers as reference for surgical and anesthetic procedures (Monazzi et al., 2012; Carvalho et al., 2003). Those anatomic structures are of clinical significance for the maxillofacial surgeon because of their relation to the inferior alveolar nerve (Jansisyanont et al., 2009; Kositbowornchai et al., 2007; Tuli et al., 2000; Cillo \& Stella, 2005; Balcioglu et al., 2010).

Studies on the location of the mandibular foramen (MF) provide the practitioner with improved awareness of MF location, thus, lowering the risk of having the inferior alveolar nerve injured, as well as improving the efficacy of inferior alveolar nerve block (Nicholson, 1985; Daw et al., 1999; Valente et al., 2012; da Fontoura et al., 2002).

The lingula of the mandible is a tongue-shaped bone projection on the medial aspect of the ramus, which lies in close proximity to the anterior margin of the mandibular foramen (Monazzi et al.; Jansisyanont et al.; Kim et al., 1997). Lingula has been an important landmark to perform the sagittal split ramus osteotomy (SSRO), the most widely used surgical technique for correction of mandible positioning. On SSRO, the horizontal cut on the medial aspect of the mandible is done just above to the lingual (Cillo \& Stella; Tom et al., 1997).

However, it is important to note that the level at which the lingula is found varies among individuals and can even differ from side to side in a same person. Such variation implies a certain risk of injuring the inferior alveolar nerve (Jansisyanont et al.; Kositbowornchai et al.; Fernandes et al., 2009). Furthermore, few are the studies focusing more carefully on the anatomic structures related to the area where SSRO of the mandibular ramus is performed (Balcioglu et al.).

\footnotetext{
* Departamento de Ciências da Vida, Universidade do Estado da Bahia, Bahia, Brazil.

** Escola Bahiana de Medicina e Saúde Pública, Bahia, Brazil.

**** Departamento de Diagnóstico Oral, Faculdade de Odontologia, Universidade de Campinas, São Paulo, Brazil.
} 
Craniofacial measurements is a scientific study that aims to better understand the complex anatomical standards of head and face (Golalipour et al., 2007; Shah \& Jadhav, 2004). Measurements taken on many cephalic aspects have been linked to the cephalic index as a means of characterizing repetitive patterns of anatomical occurrences. Viewed as the most important dimensional relation of cephalic measurements the cephalic index - the ratio of the maximum width of the head to its maximum length, multiplied by 100 - classifies the shape of the human head into dolichocephalic, mesocephlic brachicephlic and hyperbrachycephalic, ranging from the longest to the shortest (Williams et al., 1995; Iwaki et al., 2011).

The aim of the current study was to topographically determine the anatomical location of the mandibular foramen and respective lingula in dry human mandibles and to establish whether it bears a relationship with cephalic index of the respective crania.

\section{MATERIAL AND METHOD}

This study received the approval of the institutional ethics committee of the Fundação Bahiana para Desenvolvimento das Ciências, Bahia,Brazil (CAAE N. 17099213.5.0000.5544) and was performed on 105 cadaveric dentate dry hemi-mandibles, from both male and female adult South American humans obtained from the Bahia State University, São Paulo Federal University and Bahiana School of Medicine and Public Health.

The hemi-mandibles studied were from dolichocephalic $(n=35)$, brachycephalic $(n=35)$ and mesocephalic $(n=35)$ heads, all free from macroscopic abnormalities and having, at least, a steady, well-formed, not-decayed and orthodontically well-positioned second molar.

Anatomic Landmarks. In this study, the mandibular foramen and lingula were characterized by point $\mathrm{F}$, the lowest point of the margin of the foramen, and point $\mathrm{T}$, the tip of the lingula.

The bone landmarks used to describe the topological situation of the mandibular foramen were: the lowest point of the mandibular incisure (I); the higher point of the inferior margin of the mandibular ramus (B); the most posterior point on the anterior margin of the mandibular ramus (A); the most anterior point on the posterior margin of the mandibular ramus $(\mathrm{P})$.

With the lateral aspect of each hemi-mandible lying on a flat, horizontal surface, and a digital camera positioned 15 $\mathrm{mm}$ above aiming at the medial aspect of the ramus, a picture was taken with the posterior margin of the ramus vertically positioned as referred to the image on focus. The angles obtained on this photographic composition are similar to that observed when the mouth is open.

Reference points I, B, A and P were firstly determined on the images taken using computer software. Points I and $\mathrm{B}$ were established by tangency with a horizontal straight line, whereas tangency with a vertical one defined points A and P (Fig. 1)

Morphometric analysis. All measurements were performed directly on each hemi-mandible having as additional guide the respective, prior graphical predeterminations of the study topological references. All the measurements were carried out in millimeters by the same investigator using a digital caliper (Mitutoyo - Mycal Absolute - 500 series - 500-144 B).

The vertical distances from F, F-I and F-B, and the horizontal ones, F-A and F-P, were determined and used to establish the height and width of the mandibular ramus by adding $\mathrm{F}-\mathrm{I}$ to $\mathrm{F}-\mathrm{B}$, and $\mathrm{F}-\mathrm{A}$ to $\mathrm{F}-\mathrm{P}$.

The height of the lingula $(\mathrm{Hl})$ was defined as the distance between its tip point $(\mathrm{T})$ and the point where the upper margin of the lingula merges into the continuous medial aspect of the ramus $(\mathrm{Z})$, according to (Fernandes et al.).

Another topological association studied was that between the level of the occlusal surface of the second molar and the level of point $F$ referred to as height of point $F(\mathrm{Hf})$. Before taking Hf directly on study specimens, the predetermination of reference points were performed on the digital picture of each hemi-mandible. Using computer software a vertical line through point $F$ was drawn. Intersecting this line, a second one running just above the occlusion surface of the second molar was drawn. The intersection of these 2 lines determined point $\mathrm{M}$ and the distance between points $\mathrm{M}$ and $\mathrm{F}$ was defined as $\mathrm{Hf}$, which was recorded as positive if $\mathrm{M}$ lied below $\mathrm{F}$, and negative otherwise excepting $\mathrm{M}$ and $\mathrm{F}$ at the same level, in which case Hf was zero (Fig. 1).

Statistical Analysis. Distances were grouped according to the cephalic indexes and analyzed for differences using parametric one-way analysis of variance (ANOVA).

Confirmation of differences was carried out using Tukey's honestly significant differences (THSD) test.

Level of statistical significance was set at 0.05 and analyses were performed in $\mathrm{R}$ statistical package version 3.1.0 (2013), R Development Core Team. R: A language and environment for statistical computing (Vienna, Austria: R Foundation for Statistical Computing; 2013, http://www.R-project.org). 


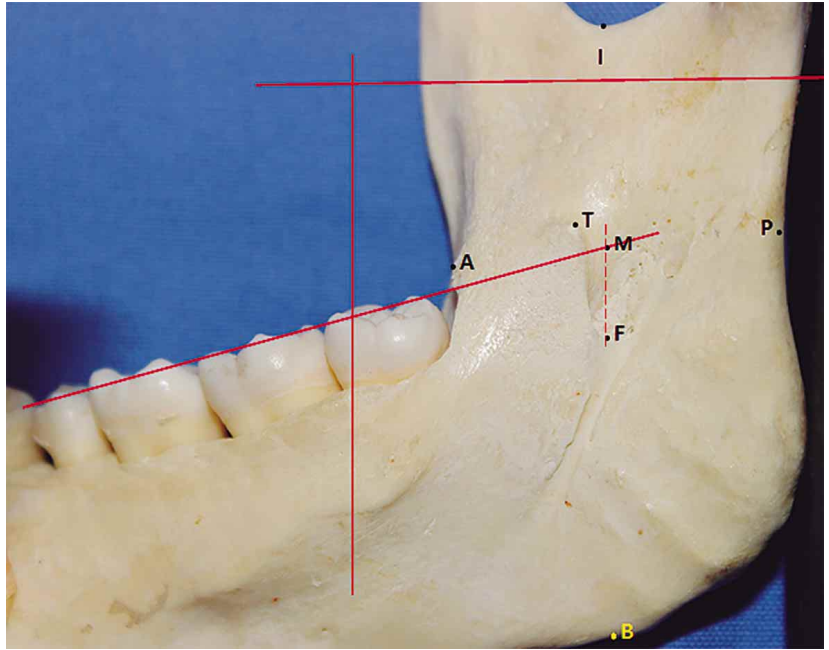

Fig. 1. Medial view of the mandibular ramus. By displacing the vertical continuous red line, the most posterior $(\mathrm{A})$ and anterior $(\mathrm{P})$ point on the mandibular ramus were determined. Likewise, by displacing the horizontal continuous red line, the lowest point of the mandibular incisures (I), and he highest point of the inferior mandibular base (B) were determined. The tip of the lingual $(\mathrm{T})$, the most inferior point of the mandibular foramen $(\mathrm{F})$, and the reference point $(\mathrm{M})$ used to indicate the height of the mandibular foramen. $\mathrm{M}$ was determined as the intersection of the red continuous line marking out the second molar occlusal plane and the vertical dotted line going through point $\mathrm{F}$.

\section{RESULTS}

ANOVA F-test showed no statistically significant difference in the height of mandibular ramus, determined as the addition of the measures $\mathrm{F}-\mathrm{I}$ and $\mathrm{F}-\mathrm{B}$ when comparing different cephalic indexes. Brachycephalic mandibles, however, were less wide, as determined by the addition of measures F-A and F-P, than meso- or dolicephalic ones (Table I).

Both ANOVA F- and THSD test showed that the mandibular foramen (point $\mathrm{F}$ ) was closer to the anterior margin of the ramus (point A) in brachycephalic mandibles as compared with meso- and dolicho cephalic ones (Table II).

Likewise, brachycephalic mandibles showed their mandibular foramen lying at a higher level as compared with meso- and dolichocephalic specimens with mean determinations of $\mathrm{Hf}$ in brachy-, meso- and dolicephalic mandibles of $-0.22 \mathrm{~mm},-4.04 \mathrm{~mm}$ and $-4.01 \mathrm{~mm}$, respectively (Table III and Fig. 2).

The mean height of the lingula $(\mathrm{Hl})$ in doli-, mesoand brachycephalic study hemi-mandibles were $1.84 \mathrm{~mm}$,

Table I. Comparison of height and width of the ramus according to cephalic index.

\begin{tabular}{|c|c|c|c|c|c|c|c|}
\hline Measurement & $\mathbf{n}$ & Cephalic Index & Mean & SD & Min. & Max. & $p^{*}$ \\
\hline Height & 105 & Dolichocephaly & 49.49 & 5.45 & 36.88 & 58.93 & \multirow{3}{*}{0.52} \\
\hline \multirow[t]{2}{*}{$(\mathrm{FI} / \mathrm{FB})$} & & Mesocephaly & 48.25 & 5.25 & 37.94 & 62.23 & \\
\hline & & Brachycephaly & 48.01 & 6.62 & 22.47 & 58.01 & \\
\hline Width & 105 & Dolichocephaly & 32.40 & 3.95 & 23.31 & 42.34 & \multirow{3}{*}{$0.066^{* *}$} \\
\hline \multirow[t]{2}{*}{ (FA/FP) } & & Mesocephaly & 31.82 & 2.92 & 26.58 & 40.40 & \\
\hline & & Brachycephaly & 30.44 & 3.72 & 23.60 & 39.90 & \\
\hline
\end{tabular}

$*=$ ANOVA - statistical F $; *$ = Statistically significant

Table II. Comparison of foramen location on the medial aspect of ramus according to cephalic index.

\begin{tabular}{|c|c|c|c|c|c|c|c|}
\hline Measurement & $\mathbf{n}$ & Cephalic Index & Mean & SD & Min. & Max. & p* \\
\hline \multirow[t]{3}{*}{ FA } & 105 & Dolichocephaly & 18.70 & 2.45 & 14.01 & 24.59 & \\
\hline & & Mesocephaly & 18.50 & 2.28 & 12.46 & 23.09 & $0.0089 * *$ \\
\hline & & Brachycephaly & 17.09 & 2.26 & 12.80 & 21.75 & \\
\hline \multirow[t]{3}{*}{ FP } & 105 & Dolichocephaly & 13.70 & 2.63 & 9.30 & 19.16 & \\
\hline & & Mesocephaly & 13.32 & 1.80 & 9.07 & 17.44 & 0.73 \\
\hline & & Brachycephaly & 13.35 & 2.17 & 9.02 & 18.93 & \\
\hline \multirow[t]{3}{*}{ FI } & 105 & Dolichocephaly & 23.56 & 3.05 & 18.73 & 31.90 & \\
\hline & & Mesocephaly & 23.68 & 2.47 & 17.58 & 28.66 & 0.3 \\
\hline & & Brachycephaly & 24.48 & 2.50 & 20.22 & 30.22 & \\
\hline \multirow[t]{3}{*}{ FB } & 105 & Dolichocephaly & 25.94 & 4.58 & 16.83 & 33.51 & \\
\hline & & Mesocephaly & 24.57 & 4.39 & 15.78 & 35.79 & 0.19 \\
\hline & & Brachycephaly & 24.09 & 4.04 & 16.73 & 33.09 & \\
\hline Measurement & $\mathbf{p}^{*}$ & \multicolumn{4}{|c|}{ Comparison } & \multicolumn{2}{|c|}{$\mathbf{P} \mathbf{a d j} * * *$} \\
\hline \multirow[t]{3}{*}{ FA } & \multirow[t]{3}{*}{$0.0089^{* *}$} & \multicolumn{4}{|c|}{ Mesocephaly = Dolichocephaly } & \multicolumn{2}{|c|}{0.93381} \\
\hline & & \multirow{2}{*}{\multicolumn{4}{|c|}{$\begin{array}{c}\text { Brachycephaly }<\text { Dolichocephaly } \\
\text { Brachycephaly }<\text { Mesocephaly }\end{array}$}} & \multicolumn{2}{|c|}{$0.01323 * *$} \\
\hline & & & & & & \multicolumn{2}{|c|}{$0.03427 * *$} \\
\hline
\end{tabular}

$*=$ ANOVA - statistical F; $* *=$ Statistically significant; $* * *=$ Tukey test (Post Hoc Test). 
$1.3 \mathrm{~mm}$ and $0.78 \mathrm{~mm}$, respectively, with THSD test showing statistically significant larger mean value of $\mathrm{Hl}$ in dolicephalic specimens as compared with bradycephalic ones (Table IV and Fig. 3).

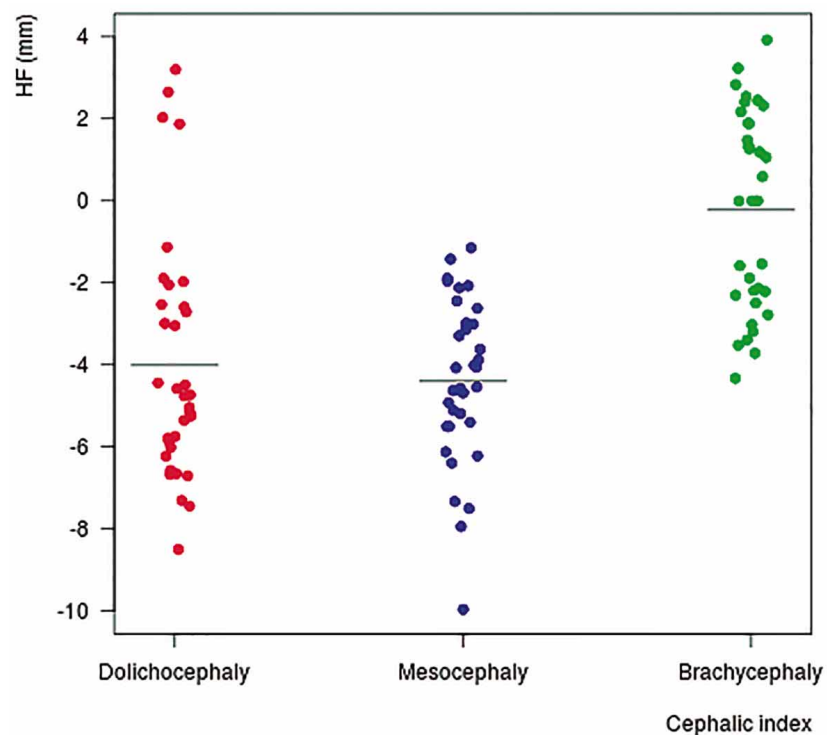

Fig. 2. Dot plot graphic showing the height of mandibular foramen according cephalic index specimen.
Regardless of their cephalic index classification, minimum, mean and maximum measurements of $\mathrm{Hf}$ and $\mathrm{Hl}$ obtained in this study's sample were $\{-9.96 \mathrm{~mm} ;-2.87 \mathrm{~mm}$; and $+3.92 \mathrm{~mm}\}$ and $\{0.00 \mathrm{~mm} ; 1.31 \mathrm{~mm}$; and $5.66 \mathrm{~mm}$, respectively (Table V).

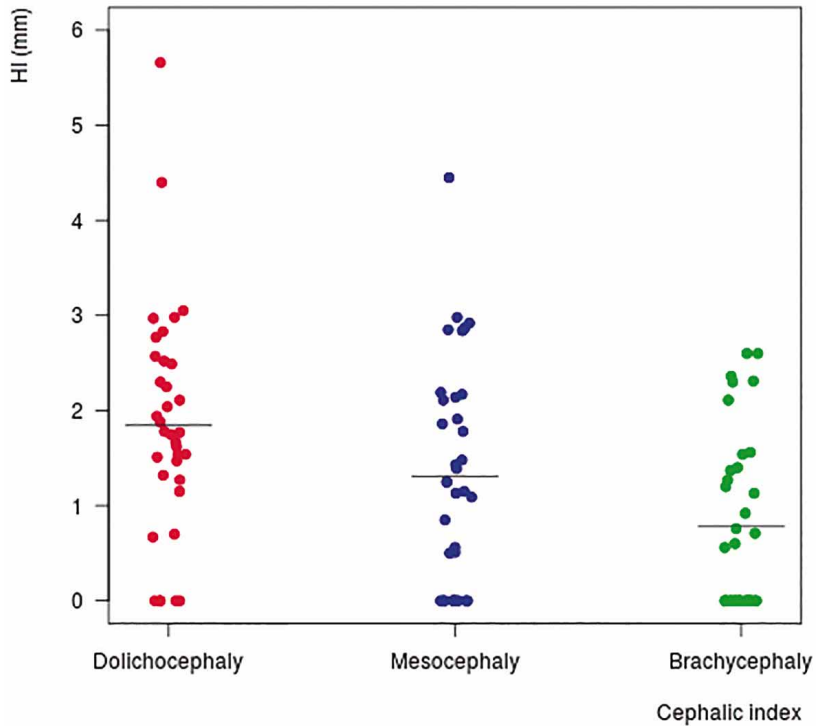

Fig. 3. Dot plot graphic showing the height of the lingula according cephalic index specimen.

Table III. Height of the mandibular foramen (Hf) according to cephalic index.

\begin{tabular}{|c|c|c|c|c|c|c|c|}
\hline Measurement & $\mathbf{n}$ & Cephalic Index & Mean & SD & Min. & Max. & $\mathbf{p}^{*}$ \\
\hline \multirow[t]{3}{*}{$\mathrm{Hf}$} & 105 & Dolichocephaly & -4.01 & 2.95 & -8.50 & 3.20 & \multirow{3}{*}{$0.00000000004284089 * *$} \\
\hline & & Mesocephaly & -4.04 & 1.99 & -9.96 & -1.15 & \\
\hline & & Brachycephaly & -0.22 & 2.39 & -4.33 & 3.92 & \\
\hline Measurement & & $\mathbf{p}^{*}$ & \multicolumn{4}{|c|}{ Comparison } & $\mathbf{P} \operatorname{adj}^{* * *}$ \\
\hline \multirow[t]{3}{*}{$\mathrm{Hf}$} & \multirow{3}{*}{\multicolumn{2}{|c|}{$\begin{array}{c}0.00000000004284089^{*} \\
*\end{array}$}} & \multicolumn{4}{|c|}{ Mesocephaly = Dolichocephaly } & 0.78648 \\
\hline & & & \multirow{2}{*}{\multicolumn{4}{|c|}{$\begin{array}{c}\text { Brachycephaly }>\text { Dolichocephaly } \\
\text { Brachycephaly }>\text { Mesocephaly }\end{array}$}} & $0.00000 * *$ \\
\hline & & & & & & & $0.00000 * *$ \\
\hline
\end{tabular}

$*=$ ANOVA - statistical F; $* *=$ Statistically significant; $* * *=$ Tukey test (Post Hoc Test).

Table IV. Height of the lingula (Hl) according to cephalic index.

\begin{tabular}{|c|c|c|c|c|c|c|c|c|}
\hline \multirow{4}{*}{$\begin{array}{l}\text { Measurement } \\
\mathrm{H} 1\end{array}$} & $\mathbf{n}$ & Ceph & lic Index & Mean & SD & Min. & Max. & $\mathbf{p}^{*}$ \\
\hline & \multirow[t]{3}{*}{105} & Dolic & ocephaly & 1.84 & 1.21 & 0.00 & 5.66 & \multirow{3}{*}{$0.00053 * *$} \\
\hline & & & & 1.30 & 1.16 & 0.00 & 4.45 & \\
\hline & & \multicolumn{2}{|c|}{ Brachycephaly } & 0.78 & 0.91 & 0.00 & 2.60 & \\
\hline Measurement & \multicolumn{3}{|c|}{$\mathbf{p}^{*}$} & \multicolumn{3}{|c|}{ Comparison } & \multicolumn{2}{|r|}{$P \operatorname{adj} * * *$} \\
\hline \multirow[t]{3}{*}{$\mathrm{H} 1$} & \multirow{3}{*}{\multicolumn{2}{|c|}{$0.00053^{* *}$}} & \multicolumn{4}{|c|}{ Mesocephaly = Dolichocephaly } & \multicolumn{2}{|r|}{0.10707} \\
\hline & & & \multicolumn{4}{|c|}{ Brachycephaly $<$ Dolichocephaly } & \multicolumn{2}{|r|}{$0.00031 * *$} \\
\hline & & & \multicolumn{4}{|c|}{ Brachycephaly $=$ Mesocephaly } & \multicolumn{2}{|r|}{0.11996} \\
\hline
\end{tabular}

$*=$ ANOVA - statistical F; $* *=$ Statistically significant; $* * *=$ Tukey test (Post Hoc Test).

Table V. Height of the mandibular foramen $(\mathrm{Hf})$ and lingula $(\mathrm{Hl})$ without considering cephalic index.

\begin{tabular}{lccccc}
\hline Measurement & n & Mean & SD & Min. & Max. \\
\hline Hf & 105 & -2.87 & 3.10 & -9.96 & 3.92 \\
Hl & 105 & 1.31 & 1.18 & 0.00 & 5.66
\end{tabular}




\section{DISCUSSION}

The relation that the mandibular foramen bears to the inferior alveolar nerve makes this foramen a major feature when administering anesthetics or performing surgical procedures.

Situated at the centre of the medial aspect of the mandibular ramus, inferiorly and posteriorly to the lingula, the mandibular foramen shows no differences regarding shape, size and location when comparing its features on the left and right side of the mandible (Iwaki et al.; Valente et al.; Ennes \& Medeiros, 2009; Martone et al., 1993).

Previous studies on dry mandibles have reported mean values of the distance of the mandibular foramen to the anterior margin of the ramus as $17.67 \mathrm{~mm}$ (Monnazzi et al.), $20.70 \mathrm{~mm}$ (Kositbowornchai et al.), $14.6 \mathrm{~mm}$ - for both sides (Ennes \& Medeiros), $17.63 \mathrm{~mm}$ - for right side and $18.45 \mathrm{~mm}$ - for left side (Carvalho et al.), $16.94 \mathrm{~mm}$ - for right side and $17.32 \mathrm{~mm}$ - for left side (Valente et al.), 17.65 $\mathrm{mm}$ - for right side and $18.04 \mathrm{~mm}$ - for left side (Reis et al., 1997). The present investigation, in turn, studied the distance of the foramen reference point $\mathrm{F}$ from point $\mathrm{A}$ on the anterior margin of the ramus $(\mathrm{F}-\mathrm{A})$ associating it with the cephalic index and found mean values of $18.70 \mathrm{~mm}, 18.50$ $\mathrm{mm}$ and $17.09 \mathrm{~mm}$ in doli-, meso- and brachycephalic specimens, respectively, with brachycephalic measurements bearing statistical significance as smaller than doli- and mesocefalic ones (Table II).

Judging by the distances of the mandibular foramen from the anterior margin of the ramus, it is not advisable performing anesthetic nerve block using needles about 35 $\mathrm{mm}$ long for they can potentially perforate the parotid gland injuring it and at the same time fail to produce the desired anesthetic effect. Nerve block should be carried out using shorter needles (about $25 \mathrm{~mm}$ long) instead. Similar remark was made by Ennes \& Medeiros.

The mean measurements of the distance of the mandibular foramen at point $\mathrm{F}$ to the posterior margin of the ramus (F-P) were $13.70 \mathrm{~mm}, 13.32 \mathrm{~mm}$ and $13.35 \mathrm{~mm}$ in dolicho-, meso- and brachycephalic specimens, respectively. These rates were similar to those found previously by other researchers: I) $12.1 \mathrm{~mm}$ and $12.3 \mathrm{~mm}$, by Ennes \& Medeiros; II) $14.24 \mathrm{~mm}$ and $14.03 \mathrm{~mm}$, by Valente et al.; and III) $11.81 \mathrm{~mm}$ and 11.41 , by Iwaki et al.; for the right and left sides, respectively; and IV) $14.35 \mathrm{~mm}$ by Monnazzi et al. Smaller mean rates were found by Fontoura et al.; with $10.04 \mathrm{~mm}$, and Reis et al.; with 10.47 $\mathrm{mm}$ and $10.14 \mathrm{~mm}$, for the right and left sides, respectively.
The analysis of the distances of point $F$ from the references on the anterior and posterior margins of the mandibular ramus F-A and F-P, respectively, shows that, in the sample of the present study, the mandibular foramen lies about $3 \mathrm{~mm}$ further two thirds of the ramus width $(31.55$ $\mathrm{mm}$ in average) from the anterior towards the posterior margin at the level of points $\mathrm{A}$ and $\mathrm{P}$.

Vertically, the mandibular foramen is located in the middle third of the medial aspect of the mandibular ramus. Our mean F-I measurements in dolicho- meso- and brachycephalic specimens were $23.56 \mathrm{~mm}, 23.68 \mathrm{~mm}$ and $24.48 \mathrm{~mm}$, respectively. Previous authors reported similar values, Kositbowornchai et al.: $24.54 \mathrm{~mm}$, Valente et al.: $24.12 \mathrm{~mm}$ and $23.65 \mathrm{~mm}$ for the right left side, Monnazzi et al.: $21.89 \mathrm{~mm}$, and Ennes \& Medeiros: $24.3 \mathrm{~mm}$ and 24.4 $\mathrm{mm}$ for the right and left side. On the other hand, Carvalho et al., and Fontoura et al., reported considerably smaller rates of $16.08 \mathrm{~mm}$ and $15.8 \mathrm{~mm}$, respectively.

Regarding height and width of the mandibular ramus, the findings of the current study were similar to those by Fontoura et al., with $49.4 \mathrm{~mm}$ and $31.03 \mathrm{~mm}$, and Ennes \& Medeiros: with $46.6 \mathrm{~mm}$ and $26.8 \mathrm{~mm}$, and $46.8 \mathrm{~mm}$ and $26.1 \mathrm{~mm}$, for the right and left sides, respectively. The statistical analysis of our findings, however, evidenced that the ramus of brachicephalic hemi-mandibles were significantly less wide those of dolicho- and mesocephalic ones (Table I).

Anatomical landmarks that indicate the location of the mandibular foramen are highly important for carrying out the block of the inferior alveolar nerve. However, the level of the mandibular foramen presents many variations according the authors: Hwang et al. (1990): $4.16 \mathrm{~mm}$ above the occlusal plane; Nicholson: $75 \%$ below surface of the molar teeth and 22\% at the same level; Afsar et al. (1998): the same level of molar teeth; Mbajiorgu (2000): $47.1 \%$ the same level of the occlusal plane, 29.4\% above and $23.5 \%$ below the occlusal plane; Monnazzi et al.: $0.02 \mathrm{~mm}$ below of the alveolar bone margin plane; Jansisyanont et al.: 4.5 $\mathrm{mm}$ above the occlusal plane.

The present study determined that point $\mathrm{F}$, our topological reference of the mandibular foramen, lied 0.22 $\mathrm{mm}, 4.01 \mathrm{~mm}$ and $4.02 \mathrm{~mm}$ below the occlusal surface of the second molar, in brachy, dolicho and mesocephalic study hemi-mandibles, respectively, thus showing that in brachycephalic specimens, point $\mathrm{F}$ was found at a higher level (Fig. 2). Based on this finding, inserting the needle 4 $\mathrm{mm}$ above the occlusion level of the molar is enough to go through the pterygomandibular space without difficulty in order to perform the inferior alveolar nerve block. 
The lingula is generally a sharp tongue-shaped bony projection located on the internal surface of the mandibular ramus to which the sphenomandibular ligament is attached. Many variations in the shape of the lingula, however, have been described (Jansisyanont et al.; Kositbowornchai et al.; Tuli et al.; Varma \& Sameer, 2013; Lopes et al., 2010).

The sagittal split ramus osteotomy (SSRO) of the ramus of the mandible is commonly performed in the surgical correction of dentofacial deformities (Tsuji et al., 2005). SSRO normally requires a horizontal osteotomy in the medial aspect of the mandibular ramus, which most frequently is performed above the mandibular foramen and at a level below that where both buccal and lingual cortical bone layers merge. The distinct feature of the lingula on the medial aspect of the mandibular ramus, makes it a very convenient landmark for referring the level of cortical merge (Smith et al., 1991), for example, reports that the fusion of both cortical structures occurs 7.5 to $13.3 \mathrm{~mm}$ above the lingula.

The height of the lingula has also been the focus of many studies. Its average measurement has been reported as $8.2 \mathrm{~mm}$ regardless of the side (Jansisyanont et al.), 8.7 $\mathrm{mm}$ and $8.2 \mathrm{~mm}$ for the right and left side respectively (Viravudth \& Plakornkul, 1989) and $8.6 \mathrm{~mm}$ and $9.1 \mathrm{~mm}$ for the right and left side, respectively (Nicholson). The present study has determined the height of the lingula as $1.84 \mathrm{~mm}, 1.30 \mathrm{~mm}$ and $0.78 \mathrm{~mm}$ in dolycho-, meso- and brachycephalic hemi-mandibles. The evident discrepancy in values between previous and present reporting is due to the fact that previous researchers referred the height of the lingula to the lower margin of the mandibular foramen whereas the present investigators referred it to the point at which the lingula merges into the medial aspect of the mandibular ramus. This point was referred to as point $\mathrm{Z}$ in a previous study by Fernandes et al.

The design of the present study evidenced that if the height of the lingula is to be used as a reference to judge the level of the medial horizontal cut to carry out SSRO, special attention should be given to the patient's cephalic index, as the present findings show that in average measurements of the height of the lingula in brachycephalic head can be less than the half of that in dolichocephalic ones.

\section{ACKNOWLEDGMENTS}

The authors gratefully thank Associate Professor Dr. Luis Garcia Alonso, Department of Morphological Sciences, São Paulo Federal University (UNIFESP).
FERNANDES, A. C. S.; LOUREIRO, R. P.; OLIVEIRA, L. \& DE MORAES, M. Localización del foramen mandibular y altura de la língula mandibular en mandíbulas dentadas secas, y su relación con el índice cefálico. Int. J. Morphol., 33(3):1038-1044, 2015.

RESUMEN: El foramen mandibular y la língula son los puntos anatómicos más importantes a considerar en la administración de anestesia troncular o la realización de procedimientos quirúrgicos en la mandíbula. El objeivo fue determinar si las características topológicas del foramen mandibular (FM) y la língula mandibular presentan variaciones en las mandíbulas de cráneos con diferentes índices cefálicos. Fueron utilizados 105 mandíbulas secas, pertenecientes a cráneos identificados como dolico, meso y braquicéfalos. En cada caso, se relacionaron la ubicación del FM con los márgenes longitudinales de la rama mandibular (RM) y la altura del foramen (Af) con la línea oclusal del segundo molar. Además, se determinó la altura de la língula (Al). En promedio, el FM de mandíbulas braquicefálicas se encontró más cerca del margen anterior de la RM. La Af en mandíbulas braqui, meso y dolicocéfalas fue de $-0,22 \mathrm{~mm},-4,04 \mathrm{~mm}$ y $-4,01 \mathrm{~mm}$, respectivamente. La língula mandibular en muestras braquicefálicas, fue considerablemente más corta $(0,78 \mathrm{~mm})$ que en las dolicocéfalas $(1,84$ $\mathrm{mm}$ ). El bloqueo del nervio alveolar inferior debe llevarse a cabo usando agujas cortas, insertándolas $4 \mathrm{~mm}$ por encima del nivel de oclusión de los dientes molares. La rama de las mandíbulas braquicefálicas fueron significativamente menos anchas que en cráneos dolico y mesocefálicos. Si la altura de la língula mandibular se utilizará como referencia para determinar el nivel del corte medial horizontal para realizar la osteotomía sagital de la rama mandibular, se debe dar especial atención al índice cefálico del paciente.

PALABRAS CLAVE: Língula mandibular; Foramen mandibular; Índice cefálico.

\section{REFERENCES}

Afsar, A.; Haas, D. A.; Rossouw, P. E. \& Wood, R. E. Radiographic localization of mandibular anesthesia landmarks. Oral Surg. Oral Med. Oral Pathol. Oral Radiol. Endod., 86(2):234-41, 1998.

Balcioglu, H. A.; Kilic, C.; Varol, A.; Ozan, H.; Kocabiyik, N. \& Yildirim, M. A. A Morphometric study of the maxillary artery and lingula in relation to mandibular ramus osteotomies and TMJ surgery. Eur. J. Dent., 4(2):166-70, 2010.

Carvalho, P. L.; Porobello, M. C. \& Reis, S. S. P. Contribuição ao estudo da posição do forame mandibular nas radiografias panorâmicas. Arq. Odontol., 39(1):45-52, 2003.

Cillo, J. E. \& Stella, J. P. Selection of sagittal split ramus osteotomy technique based on skeletal anatomy and planned distal segment movement: current therapy. J. Oral Maxillofac. Surg., 63(1):10914, 2005.

Daw, J. L. Jr.; de la Paz, M. G.; Han, H.; Aitken, M. E. \& Patel, P. K. The mandibular foramen: an anatomic study and its relevance to the sagittal ramus osteotomy. J. Craniofac. Surg., 10(6):475-9, 1999. 
Ennes, J. P. \& Medeiros, R. M. Localization of mandibular foramen and clinical implications. Int. J. Morphol., 27(4):1305-11, 2009.

Fernandes, A. C. S.; Fraga, T. L.; Trindade Neto, A. I. \& Freitas, A. C. Delimitação morfométrica para o corte horizontal da osteotomia sagital no ramo mandibular. Rev. Cir. Traumatol. Bucomaxilofacial., 9(2):107-14, 2009.

da Fontoura, R. A.; Vasconcellos, H. A. \& Campos, A. E. Morphologic basis for the intraoral vertical ramus osteotomy: anatomic and radiographic localization of the mandibular foramen. J. Oral Maxillofac. Surg., 60(6):660-5, 2002.

Golalipour, M. J.; Jahanshashi, M. \& Haidari, K. Morphological evalution of head in Turkman males in Gorgan-North of Iran. Int. J. Morphol., 25(1):99-102, 2007.

Hwang, T. J.; Hsu, S. C.; Huang, Q. F. \& Guo, M. K. Age changes in location of mandibular foramen. Zhonghua Ya Yi Хие Hui Za Zhi, 9(3):98-103,1990.

Iwaki, L. C. V.; Iwaki Filho, L.; da Silva, M. C.; Candido, G. C.; Kiyochi Júnior, H. J. \& Gai Aita, T. Estudo morfométrico da distorção do forame mandibular em radiografias panorâmicas como auxiliar na osteotomia vertical intrabucal do ramo mandibular. R. F. O., 16(1):36-42, 2011.

Jansisyanont, P.; Apinhasmit, W. \& Chompoopong, S. Shape, height, and location of the lingula for sagittal ramus osteotomy in Thais. Clin. Anat., 22(7):787-93, 2009.

Kim, H. J.; Lee, H. Y.; Chung, I. H.; Cha, I. H. \& Yi, C. K. Mandibular anatomy related to sagittal split ramus osteotomy in Koreans. Yonsei Med. J., 38(1):19-25, 1997.

Kositbowornchai, S.; Siritapetawee, M.; Damrongrungruang, T.; Khongkankong, W.; Chatrchaiwiwatana, S.; Khamanarong, K. \& Chanthaooplee, T. Shape of the lingual and its localization by panoramic radiograph versus dry mandibular measurement. Surg. Radiol. Anat., 29(8):689-94, 2007.

Lopes, P. T. C.; Pereira, G. A. M. \& Santos, A. M. P. V. Morphological analysis of the lingula in dry mandibles of individuals in Southern Brazil. J. Morphol. Sci., 27(3-4):136-8, 2010.

Martone, C. H.; Ben-Josef, A. M.; Wolf, S. M. \& Mintz, S. M. Dimorphic study of surgical anatomic landmarks of the lateral ramus of the mandible. Oral Surg. Oral Med. Oral Pathol., 75(4):436-8, 1993.

Mbajiorgu, E. F. A study of the position of the mandibular foramen in adult black Zimbabwean mandibles. Cent. Afr. J. Med., 46(7):18490, 2000 .

Monnazzi, M. S.; Passeri, L. A.; Gabrielli, M. F.; Bolini, P. D.; de Carvalho, W. R. \& da Costa Machado, H. Anatomic study of the mandibular foramen, lingula and antilingula in dry mandibles, and its statistical relationship between the true lingula and the antilingula. Int. J. Oral Maxillofac. Surg., 41(1):74-8, 2012.

Nicholson, M. L. A study of the position of the mandibular foramen in the adult human mandible. Anat. Rec., 212(1):110-2, 1985.
Reis, L. R.; Ferreira, S. S. \& Stahlke, H. N. Seleção de elementos anatômicos de referência do esplancnocrânio para a localização do nervo alveolar inferior, no homem. Acta. Biol. Par., 6(1, 2, 3, 4):9-20, 1977.

Shah, G. V. \& Jadhav, H. R. The study of cephalic index in students of Gujarat. J. Anat. Soc. India, 53(1):25-6, 2004.

Smith, B. R.; Rajchel, J. L.; Waite, D. E. \& Read, L. Mandibular ramus anatomy as it relates to the medial osteotomy of the sagittal split ramus osteotomy. J. Oral Maxillofac. Surg., 49(2):112-6, 1991.

Tom, W. K.; Martone, C. H. \& Mintz, S. M. A study of mandibular ramus anatomy and its significance to sagittal split osteotomy. Int. J. Oral Maxillofac. Surg., 26(3):176-8, 1997.

Tsuji, Y.; Muto, T.; Kawakami, J. \& Takeda, S. Computed tomographic analysis of the position and course of the mandibular canal: relevance to the sagittal split ramus osteotomy. Int. J. Oral Maxillofac. Surg., 34(3):243-6, 2005.

Tuli, A.; Choudhry, R.; Choudhry, S.; Raheja, S. \& Agarwal, S. Variation in shape of the lingula in the adult human mandible. J. Anat., 197(Pt. 2):313-7, 2000 .

Valente, V. B.; Arita, W. M.; Gonçalves, P. C. G.; Campos, J. A. D. B. $\&$ Capote, T. S. O. Location of the mandibular foramen according to the amount of dental alveoli. Int. J. Morphol., 30(1):77-81, 2012.

Varma, C. L. \& Sameer, P. A. Morphological variations of lingula in South Indian mandibles. Res. Rev. J. Med. Health Sci., 2(1):31-4, 2013.

Viravudth, Y. \& Plakornkul, V. The mandibular foramen in Thais. Siriraj Med. J., 41(10):551-4, 1989.

Williams, P. L.; Warwick, R.; Dyson, M. \& Bannister, L. H. Gray Anatomia. 37th ed. Rio de Janeiro, Guanabara Koogan, 1995.

Correspondence to:

Atson Carlos de Souza Fernandes

Departamento de Ciências da vida (DCV)

Universidade do Estado da Bahia (UNEB)

Rua Silveira Martins, 2555, Cabula

CEP: 41.195.001

Salvador, Bahia

BRAZIL

Email: atsonfernandes@uneb.br atsonfernandes@yahoo.com.br

Received: 15-01-2015

Accepted: 17-07-2015 